\title{
VI.-CRITICAL NOTICES.
}

The Problem of Christianity. Lectures delivered at the Lowell Institute in Boston, and at Manohester College, Orford. By Josman Royoe, D.Be. (University of Orford), Professor of the History of Philosophy in Harvard University, New York. Macmillan, 1913.

THIs is a difficult book to review. It discusses a number of subjects and arrives at conclusions in each of them which, though in the author's view they are closely connected, msy appear less so to those who are not prepared to accept his system on bloc. It will be quite impossible to disouss all of them (or indeed any of them) with the thoroughness which they deserve, and in such en acoonnt of them as is possible I shall venture to depart somewhat from the order in which they are treated by Prof. Royoe himself.

Prof. Royce finds the "essence of Christianity" in the ides of salvetion through love or passionate loyalty to a community-a community of persons who themselves possess this love to the community. The love that asves is, indeed, a love towards all Imankind, but the precise good which the possessor of this love desires to promote in the objects of it is to make them members in the body which is united by the tie of mutusl love. This ides is, it is admitted, only adumbrated in the teaching of Jesus Himself. Its fall reslisetion is the grest disoovery of Bt. Paul and of the Churches which he founded. The distinguishing character of Christianity is that it is the religion in whioh this ides was for the first time, and is now, apprecisted in the fullest degree. Though the community to which the Pauline Christian felt so pasaionate a loyelty was the actual organised Christian Churah, the ides which lay at the bottom of this sentiment is, sccording to Prof. Royce, aspable of being completely detoohed from any sotual visible community. The Church of the philosophical Christian who acoopts Prof. Royoe's interpretation, is an "invisible Church," and it is never to become visible, or even (it would appear) any more visible than it is at present. And it is through union with this invisible Church thet he is to obtain salvation. The following passges will perhsps give a 8omewhat fuller ides of Prof. Royce's position :-

" First, it is needfal for me to point out that, despite certain stubborn end widespread misanderstandings, the Christion doctrine of 
love. as that dootrine appears in the parables and in the Bermon on the Mount, involves and emphsises a very positive sod activo and heroio attitude towards life, and is not, as some have supposed, a negative doctrine of passive self-surrender. And, secondly, I must also bring to your attention the fact that the Mastor's teaching about love leaves unsolved certain practical problems, problems which this very heroism and this positive tendenoy of the doctrine make by contrast all the more striking" (I., 77-78).

"Critica, as well as mistaken friends of the Master's teschings, have supposed Christian love to be more or less completely identical with self-sbnegation, - with the amisbly negative virtue of one who, as the mislesding modern phrase expresses the matter, 'has no thought of self'. Another modern expression, slso misleading, is used by some who identify Christian love with so-called 'pure altruism "" (I., 79).

"Now, against such misunderstandings, many of the wiser expounders of Christian doctrine, both in former times and in our own, have taken pains to show that love, as the Jesus of the sayings and of the parables conceived it, does not consist in mere selfabnegation, snd is not identical with pure altruism, and is both heroic and positive" (I., 79, 80).

"For the Jesus of the sayings not only rejoices in the divine love whereof every man is the object, but also invites every man to rejoice in the consciousness of this very love, and to delight also in all men, since they are God's beloved. The man whom this love of God is to transform into a perfect lover cannot henceforth merely forget or abandon the self " (I., 80).

"Every man, this self included, bas just such an unique value, and must be so viewed" (I., 81).

"But now let us return to the relation of love to the services that one is to offer to one's neighbor. What can the lover-in so far as Jesus describes His task, - what can he do for his fellow$\operatorname{man} ? "$

"To this question it is, indeed, possible to give one answer which clearly defines a duty to the neighbor; and this duty is emphasized throughout the teaching of Jesus. This daty is the requirement to use all fit.jing means,-example, precept, kindliness, non-resistance, heroism, patience, courage, strenuousness, - all means that tend to make the neighbour himself one of the lovers" (I., 85).

"Buddhism fully knows, and truly teaches, where the root of bitterness is to be found, - not in the outward deed, but in the inmost heart of the individual self. But what, so far as I know, the original Southern Buddhism never clearly made a positive part of its own plan of the salvation of mankind, is a transformation of the self, not through the mere destruction of the narrow and corrupt flesh which alienstes it from the true life, but by the simple and yet intensely positive DEVOTION of the self in a netn task, - 
to its creative office as a loyal member of a beloved community " (I., 344. 345).

"It is of course also true that Jesus daring His life had, as an individnal man, tanght a doctrine, and done a work, which made this first Christisn community possible. In this sense it is correct to say that the man Jesus, in 80 far as He was merely an individual man, is the founder of Christianity. But when we say this, we must add that, so far as we know of the teachings of the man Jesus, they did not mske explicit what proved to be precisely the most characteristic festure of Christianity, - namely, the mission and the doctrine of the Christian community itself. The doctrine of Christian love, as the Master taught it, is not yet, in explicit form, the whole Christian doctrine of life. For the Christian doctrine of life is a doctrine which 18 unintelligible apart from the ideal of the universal community" (I., 416-417).

"We are saved through and in the community. There is the victory whioh overcomes the world. There is the intsrpretation which reconciles. There is the doctrine which we teech. This, so far as we have had time, in these brief lectures, to state our osse, is our philosophy, and this doctrine, as we assert, is in agreement with what is vital in Christianty" (II., 390).

These passages will by themselves fail to do justice to the force and freshness with which Prof. Royce develops this thesis. I have heen obliged to leave out muoh of what he says about the nature of communities in general and the relation of the individual to his own community. The ideas are perheps at bottom not quite so original as the author himself seems disposed to think. But there is abundant need for their emphatic assertion, and Prof. Royce's enforcement of them constitutes a very valuable protest against many of the misrepresentations of Christianity which are current both smong theologians and among philosophers. Prof. Royce tells 08 that the extent of his Hegelianism has been exaggerated, and that he is now less of a Hegelian than he used to be. The protest is particularly important as coming from one who will at least command respect among philosophers of a Hegelisnising tendency. In making the ides of community and of love to the community into the essence of Christianity, we certainly have a new and notable departure. For it is rumarkable that, in spite of Hegel's insistence upon the community as the source of the individual's morality and spuritual life-in spite of his pushing (some of us . will say exaggerating) the idea of the social character of Morality to such a point that (as has been said) there is no moral Philosophy at all in Hegel, but only political Philosophy-both the Master himself and most Hegelianising writers on the Philosophy of Religion make singularly little of the ides of the Church. This is no doubt largely due to the extreme individuslism of Lutheranismse compared with Romenism, Calvinism, and all the religious bodies which have originated in England. Garman Philosophers and Theo- 
logians alike nardly ever seem able to shake themselves free from the Lutheran tradition. To most German Protestants the Charch is little more than " the society for maintaining public worship," while to insist much on the importance of this one function of worship which is allowed to the Church is to many liberal Protestants a note of defective "spirituality". The extreme subordination of the Church to the State in Protestant Germany finds expression in such sayings as "The State is mascaline; the Cburch is feminine". And it is chiefly among Germans and Germanising Anglo-Saxons that there has been any serious trestment of religious Philosophy or philosophical Theology. The ides that Religion is a little private transaction between "a man and his Maker" has sunk deep into the popular Protestant consciousness. Ritschlianısm (in spite of Ritschl's own idea that the Church rather than the individual Christian 18 the object of salvation) is an extreme exaggeration of this tendency. It bases the whole evidence of Religion upon the impression made upon the individual believer by the picture of Christ's personslity, and makes almost its whole content to consist in the personal relation thus established. Harnack, as Dr. Banday has remarked, seldom uses the term "Church" without some note of disparagement, and the same may be said of most German Theologians before Troelsoh, a writer to whom Prof. Royce aoknowledges his indebtedness. The Mysticism which is now becoming fashionable in England-at the opposite pole of thonght from Ritschlianism in other respects-agrees with it in this individualising tendency. The individual is supposed to discover God by his unsided reflection, and to enjoy an immediate vision of God which owes nothing to his religious community and its tradition. And ideslististic Philosophers have strengthened the tendency by babitually speaking as if, in flagrant defiance of historical fact, the "mystical "type of "religions experience" were the only one.

Against these tendencies Prof. Royce's theory is at least a very weloome and much-needed protest. Whether you look at the matter historically or psychologically, Prof. Royce 18 to my mind wholly right. If we study the lives of the mystics themselves, we find abundant evidence of the large extent to which their environment explains the experiences which they themselves-or at least rather their undiscriminating admirers-are disposed to regard as direct communications from on high. And if we look at the particular higtory of Christianity, the latest research is muking it more than ever plain that (however strongly we may assert that it was the personality of Jesus which crested the Church) it is simply impossable to discriminste (when you come to detals) between the sayings which are genuine utterances of Jesus and those which are due to the working of $\mathrm{His}$ spirit and influence in the Church. Indeed, in this matter I believe that Prof. Royce is even more right than he knows. He is, I venture to think, disposed to attribute a greater importance in the evolu- 
tion of Christianity to the personal thought of 8t. Paul than is warranted by the facts. Theologians have too often written as if the ideas of Christians had simply stood still between the taking away of their Lord and the appearance upon the scene of St. Paul. Many of the ideas which are often associated with the teaching of 8t. Paul are much more probably due to the common conscionsness of the primitive Church, though St. Paul doubtless gave them a 'eir alassical expression in religious literature. To deny or ignore all this does not really add to the personal supremacy of Jesus; for Loigy is not far wrong in saying that the greatest thing that Jesus did was to found the Church That this little body of little-eduoated Jews should have been able to originate such great idese is the best testimony to the greatness of their Master.

Bo far I can follow Prof. Royce's central ides, and I would wish to speak with the utmost respect of the brilliancy and the deep ethical and religious feeling with which that idea is developed. His paper contains the best exposition that I know of the deepest essence of Christian morality, and the best reply that I know to the current misrepresentations of it as an essentially "other worldly" or "world-renouncing" doctrine-misrepresentstions from which even Troeltsch is not altogether free. And yet I cannot but feel that there is considerable exaggeration in making this the essential ides of Christianity, whether we examine the matter historically or from the point of view of the present religious consciousness. If he had confined himself to saying that the ides of universal love-understood as he explains it-was the central ides of Christian Ethics, and that in the teaching of Jesus-not so olearly in that of St. Paul and the later Christian community - the right state of the soul was made to consist in this universal love, he would have been saying what was undeniably true. Prof. Royce has no doubt admirably expressed the difference between Chriatian love and the Buddhistio negation of self on the one hand or mere Utilitarianism on the other. It wonld, indeed, throw considerable suspicion upon Prof. Royce's clains to express what hes always been the essence of Christian Morality if we were to suppose that such an interpretation of it was absolutely new. This it certainly is not. I would refer for instance to certain chspters of Beeley's Eace Homo as containing substantially the same interpretation of Cbristian morality, it we put aside Seeley's assumptions about the actual masning of the Kingdom of Heaven to Jesus Himself which could not now be defended. Nor indeed is what Prof. Royce says about the essentiality of the Christian Boaiety to a true concoption of Chriatianity any great advance upon Beeley's exposition of it, except that Prof. Royce has formulated it in the language of techn.cal Philosophy and connected it with philosophical views about the nature of human society in general in a wry which Seeley of course did not attempt to do. But 
to make the idea of the Community into the whole essence of Christianity seems to me seriously defective.

In the first place when thus isolated from everything else in Religion and Ethics the ides of the Community tends to lose most of the characteristica which would attach any one to it. It is not, be it remsrked, the ides of universal love bat the ides of an actual community of people who pratise this love towards each other which Prof. Royce regards as the essential element in Christianity. But why should there be this passionate attachment to a community which is not the community of the human race, and why this psesionste desire to get other people into it? If the Christian Church had been nothing but a community attached to the ides of a community the attachment to it could hardly have been acoounted for. Historically the bond of union between religious communities has invariably been attachment to a common body of ideas. No doubt this very idea that Salvation to be sought by loyal service to a community which is potentially co-ertensive with mankind is itself one of the ideas which the Society possessed and was anrious to communicate to its membars, and perheps it is the most important of them But it was not all. Religions invariably involve a theory of the Universe-a Metaphysio as well as an Ethic. Of course Prof. Royce may say that he happens not to believe in the particular theory of the Universe which the early Christians professed, and that he does believe in the ethical idea just described. $\mathrm{He}$ is no doubt entitled to dream of a society which has shaken off the early Christian Metaphysic bat retains its fundamental ethioal ides. But it may be doubted whether any society cond inspire this passionate loyalty if attachment to this ides were its whole raison detre. Even if it were, this ethical ides would be logically prior to the ides of the Community. In the history of Religion what we see everywhere is that the ides comes first, the community next. It is true that from the nature of the Christian ides the Community is more necessary to the realisation of it than in the case of other Religions. A Buddhist might be served in solitnde. A Christian cannot, if the Christian doctrine of salvation (as Prof. Royce interprets it) be true. But bistorically the ardour of Christians for their community was explained by their holding in common a number of other beliefs besides this belief in the Community. And historically the belief in a God of love and a supreme revelation of Himself through a human Personality and the doctrine of a blessed Immortality to be attained through loyalty to that truth were the strongest forces which attracted men to the community. In particular it is rather sarprising that a thinker who grasps so clesrly the importance of that new ides of Christianity which converted Morality into Loyalty to a visible and concrete community should seem to bo 80 blind to the value of the equally new ides which identified it with loyalty to an ideal Being who was also an historical person. 
Loyalty to the personal Christ has been (and surely is) even a more vital element in Christianity than loyalty to the community.

At this point Prof. Royos will probably protest that I am taking too serrously his language about the "beloved community". He admits that the community does not exist in any outward and visible form. It is not any branch of the actual Christian Charah or all of them put together. It has no outward and visible existence, al 1 never will have. Now of course we all know what an ideal is, and it is the nature of the real world or, as Philosophers sey, of the phenomenal world to fall short of the ideal, and some of us msy even be disposed to recognise a profound meaning in Plato's further doctrine that after all it is the idesl that is the most truly real But what I am disposed to complain of in Prof. Royce's treatment of the subject is that there is simply no relation in his theory between the actual and the ideal. His ideal community is a xupertòr ctros-a universal which does not reside, to any extent. or in any degree, in its particulars. When be comes to actual or oven to possible Christisn societies, he has nothing but rather contemptuous expressions for them which we expect to meet with in those very writers whose view of the nsture of Religion he justly regards as over-individualıstic, and who do not understand the social character of the religion, the religious conscionsness, religious experience, religious ethics. All the things that Prof. Royce tells us about humsn society - the reality of its common life, its being a "person" and the like would simply be untrue if the society of which be spesks were merely an idesl, a city in the heavens. Much of Prof. Royce's language about the real and " personal" $\theta x-$ istence of societies seems to me somewhat exaggerated and misleading; but I am quite in sympathy with what at bottom I take him to mean, and I will assume for the moment that it is all true and accurately expressed. And the truer it is, the more it compels us to recognise that it can be true only of some actual human society or societies. No doubt the idesl is not and never will be perfectly realised by any actual, orgenised society, or by all of them put together. But Prof. Royco's practical tesching can only be applied to actual life by the existence of societies which attempt to realise the ides, and by individuals who attach themselves to whatever society seems to them the best adapted here, now, for themto represent or symbolise this great ides of the community of the redeemed. And if that is so, actual Churches and organisstions ought not to be spoken of in the rather patronising tone which Prof. Royce usually adopts towards them. In recommending to the individual at least to the philosophic individual-an attitude of complete detachment from all existing religious organiastions, all traditional creeds and systems, all signs and symbols and incarnations of the spiritual reality, Prof. Royce is, as it seems to me, practically unsaying and contradicting all the valuable teaching in the esrlier part of his work about the essentislly socisl chancter of 
Religion and of all the higher moral and spiritual life of man. He wonld be quite justified in insisting strongly-more strongly even then he has done-apon the gulf which yawns between the magnificent idesl of the Churches and their actual practice, upon the necessity for reform, for adapting their teaching to the ideas of the age and 80 on. But to suggest to the individual that he should practically be content with a Church which exists only "in the heavens "is in effect to tell him to give up that article of belief in the Churoh to which Prof. Royce attacbes so much importanco., A Universal must have particulars. A Church which existed only in the heavens would not be 8 Church at all. The inconsistency would be patent to every one if we transferred this way of thinking to the State. Undoubtedly no actual State is more than an inadequate attempt to reslise the true ideal of the State as it presented itself to a Plato, an Aristotle, or a Hegel ; bat, so far as I am aware, no one who has treated the State in the spirit of any of these philosophers has ever combined such an exalted view of the ideal State with suoh contempt for the actual State as 18 practically expressed by Prof. Royce for the actual or even for every possibly actual Church or Churches. A man who should profess sympathy with the Hegelian idea of the State and recommend Anarchism, or at least Btoic "autonomy" and detachment, in prectice would bere very inadequately learned the true lessons of Hegel's political thought.

But at this point I may be again reminded that at bottom the "beloved community" of which Prof. Royce tells us is only a name for humanity at large. 'At times Prof. Royce tells us so in so many words. But this only makes the inconsistenoy the more glaring. Doubtless mankind does form in some sense a community. But nobody knows better than Prof. Royce that a community of all mankind-at least so long as that community hes no outward and visible socisl and political organisation or expression-cannot be to the individual all that a community ought to be. It must be in lesser communities than this that the true idea of a community must be realised; and these communities must be actual, concrete, more or less organised. Does not Prof. Royce tell us that it must be the supreme effort of the members of the "beloved community" to turn other men into members of it? How can he do this if they are already members as fully as they ought to be? If it be suggested that to make them members of an ideal community is only another way of asying to produce a moral or spiritual change in them such as might be constituted by entrance into an actual community-to behave towards every other as if one were trying to make tinem members of a community, I would subuit that this is to ideslise the conception of a community to a point at which it ceases to be a community at all or to have anything in common with the Christian Church or any other of the actual religious communities of history. And yet to say this would be to ignore the lesson which Prof. Boyce's own study of Christianity so vigorously teaches. 
This account of Prof. Royce's view of the Church is not complete without some reference to his theory of Atonement. In a chapter on 'Time and Guilt' he insists upon the irrevocable obsracter and consequences of moral choice. There is, in Prof. Royce's view, a certain "actual and deliberate sin agsinst the light" $\rightarrow$ " sin agrinst the Holy Ghost," the consequences of which are irrevocable. The Hell to which by such a sin the individual is doomed, or rather to whic 1 he dooms himself, is self-chosen. The individusl who has been guilty of it will feel (or does Prof. Royce menn thet he ought to feel ? - the distinction does not seem to be recognised): "It is my precious privilege to assert my own ressonable will, by freely acoepting my place in the hell of the irrevocsble, and by never forgiving myself for this sin against the light. If any new deed can assign to just that one traitorous deed of mine any essentially novel and reconoiling meaning - that new deed will in any case certainly not be mine. I can do good deeds in future; but $I$ ounnot revoke my individual past deed "(i., 266-267). The only way in which the sin can be atoned for is that something should be done " which gives to my very treason itself a new value; so that I can say, not. 'It is undone'; but 'I am henceforth in some messure, in some genuine fashion, morally reconciled to the fact that I did this evil " " (i., 281).

The author insists on the inadequacy of the ides of substitution or of modern "moral" theories of Atonement, hke that of M. Auguate Babatier, besed on the actual effects upon the heart of self-sacrifioing love. We want an objectrve atonement. The "triumph over tresson" which is required "can only be accomplished by the community, or on behalf of the community, through some steadfastly loyal servant who acts, so to spesk, as the incranation of the very spirit of the community itself. This faithful and suffering-servant of the community may answer and confound treason by a work whose type I shall next venture to describe, in my own way, thus : First, this oreative work shall include a deed, or varions deeds, for which only just this treason furnishes the opportunity. Not treason in general, but just this individual treason shell give the occesion, and supply the condition of the crestive deed which I am in ideal describing. Without justthat tresson, this new deed (so I am supposing) could not heve been done at all. And hereupon the new deed, as I suppose, is so ingeniously devised, so concretely proctical in the good which it accomplishes, that, when you look down upon the humsn world after the now crestive deed has been done in it, you say, first, "This deed was made possible by that treason; and, secondly, The world, as transformed by thrs creative deed, is better than it would have been had all else remained the same, but had that doed of treason not been done at all. That is, the new creative deed has made the new world better than it was before the blow of treseon fell " (i., pp. 307-308). 
Prof. Royce does not pretend that the desth of the historical Christ is much more then a symbol of this ides. And yet he contends that this is something very like " the form which, as I believe, the Christian ides of atonement has always possessed when the intereste of the religious consciousness (or, if I may use the now farourite word, the suboonsciousness) of the Church, rather than the theological formulations of the theory of atonement, have been in question. Christian feeling, Christian art, Christien worship, have been fall of the sense that somehow (and how has remained indeed a mystery) there was something so precious about the work of Christ, something so divinely wise (so skilful and divinely besutiful ?) about the plan of salvation,- - thet, as a resalt of all this, after Christ's work was done, the world as a whole was a nobler and richer and worthier creation then it would have been if Adam had not sinned" (i., pp. 318-319).

To the orthodox Christisn who accepts premisees which Prof. Royoe conld not acoept, the work of Christ might perhaps be considered to have this supreme value. Bat why has the work of Christ any such value unless a "satisfaction for sin" be required such as only a sinless and divine Being could offer, or unless we accept any of the numerous orthodox theories which profess to demonstrate the necessity of such a desth? If the answer be found in the teaching, the life, the character, the self-sacrifioing love of Jesus as illustrated or supremely expressed by His desth, can these seriously be said to have a value outweighing the negative value of the sins of the whole world, apart from the effects whioh they have produced upon humsn souls and lives? And if we do say that it is the consequence upon the actusl moral condition of humun beings that gives it this suprem? value, are we not back again at a "subjective" theory of Atonement? If its value may be said to be objeotive in the sense in which all values are objective for those who believe in values at all, this might be equally alleged by the partisans of the "subjective" or " moral" theories whioh Prof. Royce regards as so inadequate: the objective value lies in a subjective effect. Or, if Prof. Royce replies that he is only thinking of what Christians in the past have felt, and that for himself the objective atonement is constituted by the supremely noble deeds of all history which have been made possible by all the "sing against the Holy Ghost," I should ask whether there is really any sense or any utility in speaking of these deeds as "atoning" for guilt? If Prof. Royce were to plead that they have actually made possible for all these sinners a repentance, a renewal, an amendment of life which was not possible without them, there might be some meaning in saying that they are atoned by the good deeds; but this Prof. Royce cannot contend, for he admits that repentance, amendment, forgiveness by the community might all be possible without any such "atoning deeds". Does he say that only by virtue of these can the individual "forgive himself"? If a man 
really says to himself : "My sin hes produced so mach good in the world that I need not now mourn over my bad deed any longer," this does not seem to me a partioularly edifying state of mind. Even if it be the fact that the quantity of good which has been introduced into the world by the atoning deeds made possible by all the sins against the light exceeds the good that would have been possible without them, I doubt the expediency of calling this an "atonc ment". If the man really persuades himself that because of these deeds his sinful act is "undone" (that is Prof. Royce's view), he surely deceives himself. The value of these 'atoning deeds' may be important from the point of view of theodicy, but it seems to me to have no religious or moral value for the individual soul seeking "reoonciliation". His doed cannot be made less bad then it was, nor his present spiritual position improved, by any such good consequences which may have flowed from his sin. He can only be restored, renewed, forgiven by that repentance which according to the teaching of Jesus was the one thing needfal for "justification," but which Prof. Royce disparages. To put my criticism in the technical language of the old Theology, Prof. Royce's doctrine of the Atonement is quite unconnected with any theory of justification, or, if there is any theory of justification, it is an intelligible and immoral theory. He does not show how Atonement of this kind can be any real value to the sinner.

And here I cannot help expressing my regret that pbilosophers who undertake to develop the inner meaning of the historical doctrines of the Christian or any other historical religion do not take the trouble to read a little more about their origin and hustory. Prof. Royce very modestly disclaims for himself any competency to deal with critical or historical questions. And yet after all the historical orign of a belief has some bearing upon its philosophical interpretation. If religious philosophers would study the origin of the Atonement doctrine, they would perbaps come to the conclusion that that origin is to be sought simply and solely in the suthority of Isaiah liii., and other prophecies of the Old Testament, messianically interpreted. If the notion of an "objective" Atonement owes its origin simply to a mistaken interpretation of documents believed to be authoritative, he will perhaps feel dispensed from finding an explanation of it elther in "Christian experience" or universal religious experience. No doubt the doctrine did appesl to very real needs and cravings of the human spirit; but, unless we are Pragmatists, we are not bound to accept doctrines as true because they are comforting -atill less becanse they were comforting to people whose intellectual envisagement of the Universe was not the same as our own. The fact that the Atonement doctrine originated neither in the teaching of Jesus nor in "Christian experience" may not prevent its having in it an element of eternal truth, but perhaps this element may be adequately expressed by something like the subjective new which commends itself to mere 
"Theologisns," like M. Babstier, who know something about the origin of the doctrines which they attempt to interpret, and whose theories Prof. Royce treate rather scornfully. If the "objective" theory was really imposed by authority, if those who attempted to explain the theory either fell into grossly immoral views or ended by substituting for it a theory which was not really objective, the philosopher is surely not bound to find an equivalent for an objective Atonement in terms of philosophical thought. That this equivalence is on Prof. Royce's own theory very problematical, is so evident that I can hardly think it will meet with much acoeptance either from really orthodor thinkers or from those who very properly want to reinterpret the truth implied in traditional Theology in terms of more modern thought.

I have been obliged to pass over much that Prof. Boyce tells us. about the nature of communities in general-much whioh he tells as that most philosophers do not understand. But there is one portion of his doctrine which is too original to be ignored. Prof. Royce has been much impressed by Prof. Pierce's purely logioal conception of "interpretation". He has remarked truly that neither those who exalt perception at the expense of conception nor those who exalt conception at the expense of perception can adequately explain the nature of our knowledge of other people's minds. My neighbour's mind is not an objeot of which I can have any direct perception, nor is it " a general or abstract charactor a type, a quality or some complex object based upon such nniversals" (ii., p. 127). Here is Prof Royce's own solution of the problem :-

"If, then, there be any cognitive process whose proper object is your neighbor's mind, this process is neither a mere conception nor yet a mere perception. Is it, then, some synthesis or combination of perceptions and conceptions? Or is it, finally, some third form of cognitive process, which is neither perception nor conception, and which cannot be completely desoribable in terms of combined peroeptions and concoptions? Now it appears that the word 'interpretation' is a convenient neme for a process which at least aims to be cognitive. And the proper object of an interpretation, as we usually employ the name, is either something of the natare of a mind, or else is a process which goes on in a mind, or, finally, is a sign or expression whereby some mind manifests. its existence and its processes" (ii., 128-129).

It is quite impossible for me adequately to expound Prof. Pierce's original theory or Prof. Royce's attempt to bring out by its aid the inmost nature of the ideal community adumbrated in the historical Christian Church as a "community of interpretation". I must be content with indicating that there is this important side of Prof. Royce's teaching which I have not been able to examine. I confess that I do not find it either very intelligible or very astiafactory. 
My general view of this remarkable work is that it contributes a most viluable element to that philosophical interpretation of Christienity which our age so badly needs but that it is in one way redundant, in another incomplete. It is redundent because it is mixed up with certain highly technical notions about communities and the nature of our knowledge of one another which will seem to many of more questionsble value in themselves and not 80 closely connected as Prof. Royce supposes with the ethical and religious tdes which he is studying; it is incomplete since it ignores meny elements in Christianity which are of equal value with the element which impresses Prof. Royce. The magnificent exposition and vindiastion of the Christian doctrine of Love and the ides of the Christian community seem to me one of the most valuable ontributions to the Philosophy of Religion which have been made by any thinker of our time. This is a most important element in Christianity, but I cannot think that it contains a full solution of "the problem of Christisnity". After all this would be too much to expect in any one work of any one writer, however eminent.

H. Rabidall.

La Trascendensa. By G. Rens1. Turin: Fratelli Bocca, 1914. Pp. xii, 523.

Tris "study of the moral problem" is interesting and often very sugge日tive, though it may be doubted whether any one but the writer will be fally satisfied with its conclusions. The author incidentally spesks of his general views in philosophy as those of a "platonising Hegelian," though his special preferences in modern philosophy eeem to be for Pascal, Malebranche, Bruno and Bchelling, and in come part Fichte, and he sees Plato mostly through the eyes of the Neo-Platonists of the Renaissance. In view of the nsture of his own moral theory it is interesting that he seems to regard Green's Prolegomena to Ethice as the great masterpiece of recont philosophy, apparently on the ground of Green's orushing examination of Hedonism.

If I had to indicate Mr. Rensi's philosophical position in a sentence, I think I should say that he combines three characteristios which are not usually all found together: he is an "Averroist," a supra-Lapsarian Calvinist, and a Latin to whom such verse as the Amores of Ovid and the Virgilian Copa sppeal as they can hardly ever have done to us men of another blood. "Clagsical " idealism (i.e. Kant and Hegel), he holds, cannot give a true account of moral facts, because it has inherited from Kant 